\title{
THE DEVELOPMENT OF SCIENCE TEACHING MODEL BY USING RESEARCH-BASED TO PROMOTE CREATIVE PROBLEM-SOLVING SKILLS OF STUDENTS OF FACULTY OF EDUCATION CHIANG MAI RAJABHAT UNIVERSITY THAILAND
}

\author{
Jutamas Noonchart, Virapong Saeng-Xuto and Kreetha Kaewkhong \\ Ph.D. Candidate (Education), Faculty of Education, Chiang Mai University, Thailand \\ DOI: 10.46609/IJSSER.2021.v06i02.011 URL: https://doi.org/10.46609/IJSSER.2021.v06i02.011
}

\begin{abstract}
The purposes of this research were to:1) develop and determine the efficiency of the science teaching model by using research-based,2) evaluate the effectiveness of the science teaching model by using research-based. 34 students who studied elementary education major of Faculty of Education at Chiang Mai Rajabhat University, 2018 were drawn to be the sample of the study. They were selected from simple random sampling. Research instruments consisted of the science teaching model by using research-based, a handbook for the model, units and lesson plans, research skills assessment forms, and creative problem-solving skills tests. The data were analyzed by Mean, Standard Deviation, a T-Test Dependent, and content analysis. The results found that: 1) the model has consisted of five elements; these were (1) principles (2) objective (3) the learning process (4) the 3-part assessments and (5) the important conditions for using the model met the efficiency of $81.36 / 76.86,2$ ) The effectiveness of the model indicated that 2.1) after using the model, the students' creative problem-solving skills were significantly higher than before the instruction at .05level,2.2) the students who had different basic abilities and learning styles had higher development of research skills from a moderate level to a high level, and had higher development of creative problem-solving skills from a low level to a moderate level, 2.3) the retention of research skills were found only in the students that had high basic abilities and low basic abilities, the collaborative learning styles and dependent learning styles, all groups of the students had retention of creative problem-solving skills at the follow-up phase.
\end{abstract}

Keywords: The science instructional model, Research-Based, Research Skills, Creative Problem-Solving Skills

\section{Introduction}

The world in the 21 st century is an era of change in science and technology advances rapidly, the development of people to be able to live in social creativity and happiness need to get a basic 


\section{International Journal of Social Science and Economic Research}

ISSN: $2455-8834$

Volume:06, Issue:02 "February 2021"

human development for the future (Treffinger, 2008). The undergraduate students are focused on the enhancement of knowledge, specialized skills, and living skills. Students can seek the knowledge to use to solve problems; one way is to use the research process in acquiring knowledge and development. The students' abilities are natural and full. According to the potential of learners using the research process in seeking knowledge that needs to have research skills as basic to solve any problem with efficiency consistent with Atkins (2013) that proposed the idea that the development of Thai people to be able to continuously learn and develop oneself. The critical processes are research processes and students that learned by using research processes which plays a role. The researcher must learn and understand. Research process and examination process of science related to the subject to be researched to be used in the variety of research appropriately (Khemmanee, 2005) consistent with the analysis results at Kasetsart University Demonstration School Program, Kamphaeng Saen Campus with Center for Research and Education Group of science learning found that course goals have set students to the thinking process and process skills with science in acquiring knowledge and solving problems. Teachers have knowledge and ability to manage classes with full potential solving skills by using research process in teaching and learning management emphasizing. Learners are important, teachers have to play a role where students can seek knowledge and develop abilities. Teachers are important people who help develop students' skills by allowing students to apply knowledge of problem-solving both in the classroom and in real life. Creative problem solving is an idea that requires both elements of problem-solving and creativity which is classified as an intellectual ability that requires learning and teaching for effective student development in developing creative problem-solving skills by promoting research and finding information to solve problems, invent new inventions, and conducting a research project (Weir, 1974).From the above study, the researcher is interested to develop a science teaching model by using researchbased to promote creative problem-solving skills of students of the Faculty of Education, Chiang Mai Rajabhat University which is a skill that is necessary for both working and living in today's society, and can create knowledge by oneself.

\section{Research Objectives}

In the research "The Development of Science Teaching Model by Using Research-Based to Promote Creative Problem-Solving Skills of Students of Faculty of Education, Chiang Mai Rajabhat University, Thailand", there is a purpose; 1) Develop and determine the efficiency of science teaching model by using research-based, and 2) Evaluate the effectiveness of science teaching model by using research-based.

\section{Methodology}

Mixed Methods Research is the methodology for the development of teaching. It has 4 steps: 


\section{International Journal of Social Science and Economic Research}

ISSN: 2455-8834

Volume:06, Issue:02 "February 2021"

Step 1: To study and analyze data fundamentals about the condition of teaching and learning of teachers and learning behavior of students in the class. Learning science in Thailand with a development focus learners and learning management guidelines for development learners according to the focus (Office of Academic Affairs and Study, 2011). The researcher analyzes concepts, theories, and research related to teaching models by starting from the theory of knowledge creation theory, intellectual development, and cultural theory. A leading society defines the principles and objectives of research-based learning concept model, self-guided learning, and collaboration to use to define instructional management guidelines according to the concept of self-study (Independent Study: IS) by synthesizing the process of patterns with 6 steps to use in teaching and learning activities in the course to develop research skills and creative problem-solving.

Step 2: To design and develop. It is developed and reviewed about model quality and tools for use model by quality checking for accuracy in oriented content of the model, unit format manual and learning management plan by holding a focus group with 9 qualified persons and inspect the quality the research skills assessment consisted of 6 skills such as research problem determination skills, hypothesis, and design skills, collect and analyze data skills, summary, and discussion skills, research presentation skills and skills in applying research results. Creative problem-solving skills Test consists of 5 skills: truth discovery skills, problem discovery skills, concepts discovery skills, problem-solving skills, and skills of knowledge creation. 5 experts consider the consistent with evaluation results, the quality of the content precision of the design, assess research skills and a skill test of solve problems creatively in each issue in the most and greatest level. There is a confidence value of 0.92 and 0.78 , respectively. Solving problems creatively has difficulty and value which is classified between 0.25-0.62 and 0.40-0.76 respectively. The results of the evaluation of the model's performance were taken with field tryout with students who are a tryout group which does not differ from the group. The sample showed the efficiency factor of Pattern $\mathrm{E}_{1} / \mathrm{E}_{2}$ equals $80.08 / 79.58$.

Step 3: To research and implement, trial model by using "The One Group Pretest - Posttest Design" and repeat measurement for testing the persistence of research skills and creatively solve problems skills. Information is collected with 4 stages: 1) Pre-school period (week 1): creative problem-solving skills test, 2) during the course (week 4) test the skills of research and creative problem solving 3) post-study period (week 7) test the skills of research problem solving, and 4) follow-up phase (Week 11) test the research skills and creative problem-solving skills. The creativity takes time to collect all information with 11 weeks.

Step 4: To develop an evaluation, 1) develop and finds model performance with student group which is an example group, and 2) evaluate the effectiveness of the model. 
International Journal of Social Science and Economic Research

ISSN: 2455-8834

Volume:06, Issue:02 "February 2021"

\section{Concept and Theory}

"The Development of Science Teaching Model by Using Research-Based to Promote Creative Problem-Solving Skills of Students of Faculty of Education, Chiang Mai Rajabhat University, Thailand", the researchers studied the principles of the concept the theory from the relevant documents and research to guide this research is as follows:

\section{Concept of teaching and learning model development}

\subsection{Definition of teaching and learning models}

For the form of teaching and learning, there are many educators in the country and abroad who have given different meanings as follows; the teaching model concludes that it refers to the condition or characteristics of the teaching arrangement that cover the key elements.It is systematically organized with a philosophical pattern, theories, principles, concepts, or beliefs, it consists of processes or procedures based on teaching methods and teaching techniques that can help the teaching conditions adhere to the principles or concepts adhered to. Therefore, an important feature of the teaching model must consist of the following:

(1) There are philosophies, theories, principles, concepts, or beliefs that are fundamental or the principle of the teaching models.

(2) Lectures or explanations of the condition or nature of the course.

(3) The system is organized, with elements and relationships of system elements to be able to lead the learner to the goal effectively it is proven and trialed for system performance.

(4) Teaching processes, teaching methods, schemes, or characteristics of the teaching arrangement are systematically held. There are philosophies, theories, principles, concepts, or beliefs based on teaching methods, and the techniques of teaching help educators to adhere to the principles, it can be used as a teacher's teaching approach to students learning according to their intended aims.

According to the study, the study has defined the teaching models, it can be concluded that the teaching model is a lesson plan that teachers can use either in the classroom or in small groups or organize teaching materials. This includes books, movies, tape recordings, computer programs, and courses, each teaching model is a concept and a theory based on collaborative problemsolving capabilities that help students achieve their intended objectives.

\subsection{Elements of an instructional model}

Tisana Khemmani (2005) explained the teaching model must have four key elements: 


\section{International Journal of Social Science and Economic Research}

ISSN: $2455-8834$

Volume:06, Issue:02 "February 2021"

(1) There are philosophies, theories, principles, concepts, or beliefs that are fundamental or the core of the teaching model.

(2) There is a lecture and explaining the condition or nature of the teaching arrangement stipulated following the principles adhered to.

(3) The system is organized, and the composition and relationship of the system elements can lead the learner to the goal of the system or process.

(4) It is explained or provided with information about teaching methods and teaching techniques that will help to maximize the efficiency of the teaching process.

\subsection{Development of teaching and learning models}

Mohan, R. (2019) has adopted the concept of organizing the development of teaching to develop a teaching model; this is a step in the right direction:

(1) Clearly define the aim of developing a teaching model.

(2) Study relevant principles/theories to define the composition and guide the relationship of the elements of the teaching model.

(3) Study the situations and related issues to help find important elements that help make the model effective when implemented. The problems and obstacles must be taken into account in the composition and relationship of the elements. The use of information from reality to create patterns eliminates or prevents problems, this will inefficiencies the format.

(4) Define elements of a pattern: determining what can help a goal or aim to achieve it. At this stage, experience, creativity, and prudence are required, therefore, it is possible to define the elements that will facilitate the success of that model.

(5) The improved teaching style must be categorized into categories, for ease of thinking and taking action on the next stage, every process has a mutual relationship.

(6) Define the relationship of an element by determining which elements are rational and consequential in such a way, what should come first, and what can be done in parallel. Therefore, at this stage, it may take a lot of consideration.

(7) Create an element relationship by demonstrating a simulated chart of elements.

(8) Try out the model to learn the consequences.

(9) Evaluate by studying the results of the pattern trial, how effective are the goals or how close they are to them?

(10) Improved format, the results of the experiment will be seen to improve the pattern using the concept of this system as a clear, easy-to-understand concept; this makes it convenient to lead the way. 
According to the educators, the development of teaching models it can be concluded that the development of the teaching style is the development of the teaching style, the creation of new knowledge by the instructor himself, based on concepts and collaborative solutions theory. The evaluation of the development of teaching models with teaching models is important in helping to improve the efficiency of teaching. Researchers are interested in Kruse's ADDIE Model. It has been adjusted in 4 steps by incorporating steps 2 and 3 into the design phase and develops together.

\section{Concepts and theories about the framework of collaborative problem solving}

In the 21 century, there was a need to develop collaborative problem-solving capabilities, an important skill that the world aims to achieve. The development of such performance must also improve the learner's thinking process. In this research, the researchers studied the concepts and related theories, as follows:

\subsection{Concepts and theories about thinking and learning}

Watchara Laoriendee (2010) has suggested the following guidelines for learning management based on knowledge building theory:

(1) From situations or issues that provoke attention, engage students in thinking and practice, dare to think, dare to answer, explain, discuss, and express opinions.

(2) Try to use information from real learning sources, real and practical, or provide real-world scenarios instead of images or other things, but avoid too many explanations, for students to have the opportunity to think.

(3) Organize activities that promote critical thinking, critical thinking, and regular thinking throughout the course.

(4) Understand the original experience stories related to the subject; provide the information needed for the search to understand new subjects to study.

(5) There are several types of student groups to allow students to collaborate, where students can exchange knowledge, thoughts, beliefs, and give sufficient time to create meaning what to learn, and assess learning results throughout the learning process and use a variety of suitable measurement and evaluation methods.

Based on the theory of knowledge and theories related to such cognitive-developmental thinking, the researchers used it as the basis for the development of the teaching model. Students can learn collaborative and content-solving processes in their own hands, researching and exchanging information with friends can reflect their conclusions in the subject stories and thought processes. 
International Journal of Social Science and Economic Research

ISSN: 2455-8834

Volume:06, Issue:02 "February 2021"

\subsection{Concepts and theories about problem-solving capabilities}

\section{1) Meaning of problem-solving thinking}

Many scholars discuss the meaning of problem-solving, for example; Karatas et al. (2017) has given the meaning problem-solving, in conclusion, it is a learning style that relies on learning two or more types of related principles, and the principle is interlocked into a new type of capability called problem-solving capability, it must be based on seeing the common nature of all stimuli. This corresponds to Scandura (2017) discusses problem-solving: "it is an activity that is both a show of knowledge, an idea from the original experience, and the components of the current problematic situation and then reordered to achieve its aims". As well as McLeod (2018) explains the theoretical problem-solving capabilities in the development of this field, this begins to develop from stage 3: stage of concrete operations. Children aged 7 to 11 years old will begin to have the ability to solve simple problems within a limited range. Later, the fourth stage of development is the stage of formal operation the child is about 11 to 15 years old. Or even Usa Jeanjenjit (2001) says that "problem-solving thinking is a cognitive ability that correlates with intelligence can be developed by individuals using the experience and knowledge skills learned before to solve new problems". This is also consistent with Suwit Moonkham (2004) said: "problem-solving is a brain capacity to eliminate imbalances by trying to adapt yourself and the environment to blend in back into the balance or expected conditions".

From the concept of solving the above problems, in conclusion, the solution means that a person can identify the problem and can use the same experience to determine the cause of the problem and decide the appropriate solution to match the cause of the problem.

\section{2) Problem-Solving Processes}

Problem-solving is characterized by a process with a step in the order of thinking, many educators have proposed, such as:

Chang (2017) believes that the thought-solving process consists of 5 steps, as follows:

(1) Preparation refers to the stage of the problem or finds out what the real problem is.

(2) Analysis refers to a process to determine what is seen as a major cause of the problem, or whatnot the main cause of the problem is.

(3) The process of proposing a solution (production) means finding a solution to the problem and then coming out in the form of a final solution.

(4) Verification refers to the process of proposing criteria to determine the results of the proposed solution, if the result is found to be incorrect, the best and most accurate solutions must be proposed until the best and most accurate methods are presented. 


\section{International Journal of Social Science and Economic Research}

ISSN: $2455-8834$

Volume:06, Issue:02 "February 2021"

(5) The re-application process means applying the correct solution for the next occasion when encountering a similar event to a problem that has already been experienced before.

In this regardEnnis (2018) said that problem-solving has six steps to the problem-solving process, as follows:

(1) Identifying a problem is the interpretation of the problem by using keywords as a guide.

(2) Analyze the problem by identifying the desired targets, including obstacles and causes.

(3) Invent a solution strategy.

(4) Carry out the Plan.

(5) Conclude by presenting the solution and presenting the evidence.

(6) Check the results by evaluating the answers.

In conclusion, concepts and theories about thinking and learning have demonstrated knowledge, understanding of thinking patterns, and learning patterns that are important for promoting the efficiency of teaching and developing learners to learn to their full potential. Also, a step-bystep thought process gives a person the ability to think about problems. Problem-solving skills when learners can identify problems and can use the same experience to determine the cause of the problem and choose the right solution to help the problem are solved effectively.

\subsection{Concepts and theories about collaborative learning}

\section{1) The meaning of collaborative learning}

Collaborative learning is a student-centered teaching event where students have different abilities by dividing students into small groups, in mutual learning, exchange of opinions, and accepting, listening to other people's opinions, and helping each other. In this regard, the students can reach their learning goals only if other members of the group reach the same goal. Their success is the success of the group (Gorgônio, Vale, Silva \& Silva, 2017).

Collaborative learning management means organizing learning activities for two or more learners or by dividing them into smaller groups. Encourage students to participate in activities together. The group consists of members of different abilities who exchange opinions and help each other and have shared responsibilities, both in their own and collectively, to achieve all of ourselves and all members of the group to achieve their goals, this is the opposite of competition and class alone (Andreu-Andrés, 2016).

The collaborative learning in this research synthesizes the meaning of collaborative learning as a teaching strategy that has the characteristics of sharing, understanding goals, and mutual acceptance, and confidence, and a clear scope of responsibility. Also, there is communication in 


\section{International Journal of Social Science and Economic Research}

ISSN: $2455-8834$

Volume:06, Issue:02 "February 2021"

the environment that is both formal and informal and the decision of the joint opinion, the instructor will be a contributor and guide students to see the solution to the problem.

\section{2) Characteristics of collaborative learning}

Collaborative learning is a method that is similar to cooperative learning. Therefore, details about the characteristics of each class must be provided to provide an accurate understanding and prevent confusion. The educators gave a perspective on the two types of learning: Hass, R. W., \& Beaty, R. E., which concluded the following:

(1) Creating positive interdependence feelings in the student group (Positive Interdependence); the methods that make students feel interdependent must be organized in teaching activities, to be reliant on the benefits of mutual group success, such as awards or scores, and interdependence in the process, work so that group work can achieve its goals. In order, each person's roles are assigned equally and are related to each other to accomplish the task and to divide the work for each student in the group, it has a contiguous appearance, but without any member, the job will not continue.

(2) A face-to-face promotive interaction is a group of students discussing, explaining, questioning, and exchanging opinions with each other, to allow each member of the group to learn and learn each other's reasons. As well as providing back-to-back information about their work, as well as helping, supporting, encouraging, encouraging and encouraging each other to work and study to achieve the group's goals.

(3) Individual accountability is the responsibility of each member's learning to be assigned to the full esteem, in the results of their learning and friends of all members of the group, the group knows who needs help and what support they need. This will encourage each other to complete the assigned work and be monitored to ensure that students are learning individually. All members of the group must be confident and ready to be tested individually to ensure that all members of the group have a shared responsibility to the group.

(4) Interpersonal and small group skills, subgroups must be trained in social skills and group work skills to work happily with others.As a result, you Students should be able to get to know each other, learn their traits, build trust in each other, and listen to and accept other people's opinions rationally. As well as knowing communication strategies and able to make decisions on how to resolve conflicts during working together effectively.

(5) Group processes are processes with procedures or methods that can help group operations effectively and achieve their goals, group members must understand their goals, including planning and implementing the plan together, and more importantly, the group's assessment 


\section{International Journal of Social Science and Economic Research}

ISSN: $2455-8834$

Volume:06, Issue:02 "February 2021"

stipulated that the group's work must be evaluated. As well as assessing the role of members, each member of the group can improve their work, how to get better? and all the members of the group help each other, also comment and decide what improvements or changes should be made. Therefore, it is evident that effective group processes are an important tool that leads to the success of the group's learning.

\section{3) Benefits of collaborative learning}

Collaborative learning has many benefits. The author would like to give examples of scholars who have mentioned such issues as Zambrano, Kirschner, Sweller \& Kirschner (2019)have discussed the benefits of collaborative learning, which can be summarized in five ways as follows:

(1) Achievement this collaborative learning is a class that allows students to collaborate, to achieve the goal of learning together, it is an opportunity for all students in the group to express their opinions and expressions, and act equally. There is mutual assistance, such as students who are good at helping students who are not good at making good students feel proud, know about time, and help them understand things better, and for students who are not good at welcoming their friends with warmth, feeling friendly and dare to ask questions, it is easier to understand the subject. The key to collaborative learning is that students in this group can work together and find the most appropriate answers, creating their knowledge that will help them gain knowledge that is truly meaningful to the students. Therefore, the student's achievement has been higher.

(2) Improving interpersonal relationships, collaborative learning provides opportunities for students of different backgrounds to collaborate rely on each other, listen to each other, understand and sympathize with group members. This has led to greater acceptance and a good relationship. This will result in a better feeling for others in society.

(3) The skills to work together for success, and maintain good social relationships, collaborative learning, cultivate skills in group work. This makes it possible for students to work with others. As a result, the group's work has been successful in following the common goal. In this regard, the social skills students will learn include leadership, trusting, decision-making, communication, conflict management, and grouping skills within the group.

(4) Collaborative skills to solve problems among group members will be to understand the common problems. Then brainstorm to help analyze the cause of the problem, and once the cause of the problem is known, Members of the group will also comment to find a solution to the problem, discussing each other's reasons. This led to a mutual agreement on which solutions would be appropriate while working together to solve the problem according to the prescribed steps and assessing the group's solution process. 
International Journal of Social Science and Economic Research

ISSN: 2455-8834

Volume:06, Issue:02 "February 2021"

(5) To recognize and realize their values, all group members will share their opinions. However, by accepting the opinions of the group members, the group's members have a sense of selfesteem and think of themselves as valuable that can help the group succeed.

\section{4) Techniques used in collaborative learning}

There are two types of collaborative learning techniques: techniques used throughout the teaching activities and techniques that are not used throughout the course. Here, researchers are interested in using techniques that are not used throughout each hour's teaching activities but may be used at any stage or in the process of teaching, or in summary, review, measurable, of a particular lesson as prescribed by the teacher.

\subsection{Collaborative problem-solving ability}

In a collaborative study of the ability to solve problems, the researchers studied the concept theories about the ability to solve collaborative problems in the following topics:

\section{1) The meaning of the ability to solve collaborative problems}

For the meaning of collaborative problem solving, some people give similar meanings in the following principles: according to a study published in psychology in the school of psychology, Ablon \& Pollastri (2018) defines a collaborative solution as a collaborative consultation between mentors, to assist with children' problems. This is in line with Dieu, Kim \& Bich (2018), which says that the existing discussions form, in addition to supporting collaborative behavior, are not only encouraging, it can also be used as a framework for collaborative solutions.In conclusion, collaborative solutions refer to a person's ability to participate in two or more joint problemsolving processes, by sharing the understanding that is, mutually acceptable and well, there is a combination of knowledge, and skills, and efforts together to solve the problem, as well as more than one way and solution that can lead all parties to the same goal and get the most out of it.

\section{2) The importance of collaborative problem solving}

Co-operation solutions (CPS) are essential and important skills in circumstances, education, and personnel. While the solution stipulated in the student evaluation program, together with the international community, involves individuals working alone in problem-solving situations, the method of solving the problem is not immediately clear. In the collaborative group of individuals together, understanding and trying and working together to solve these situations, which collaboration has different advantages over individual problem solving because it helps to achieve (1) the efficiency of dividing a person's work, (2) combination of data from multiple sources of knowledge, perspective, and experience, (3) increasing creativity and quality of 
stimulating solutions. The idea of other groups is an important skill in the 21 , requiring students to be ready for the desired occupation based on their ability to work effectively. The goal is to collaborate and use their skills to solve problems in social situations. The task of solving many of the problems that are happening in today's world is carried out by a team around the world and a growing computer economy that has observed changes in production to highlight the importance of information and knowledge services. However, even in production and work, it is hardly carried out alone, without working with others. It is also more equipped with computer networks, where individuals have greater expectations of working with diverse teams in different locations. This is by using collaborative technology (Pollastri, Ablon \& Hone, 2019).

\section{3) Collaborative problem-solving skills and performance}

A collaborative resolution performance assessment defines three core performances and is linked to four core troubleshooting processes, to demonstrate the necessary skills of collaborative solutions. The following table lists the necessary skills for collaborative troubleshooting using the PISA 2012 individual resolution process framework.

\section{Table 1: Showing the necessary performance and skills of collaborative solutions}

\begin{tabular}{|c|c|c|c|}
\hline Process & $\begin{array}{l}\text { 1. Creating and } \\
\text { maintaining } \\
\text { mutual } \\
\text { understanding }\end{array}$ & $\begin{array}{l}\text { 2. Choosing the right } \\
\text { way to solve the } \\
\text { problem }\end{array}$ & $\begin{array}{l}\text { 3. Creating and } \\
\text { maintaining group } \\
\text { regulations }\end{array}$ \\
\hline $\begin{array}{l}\text { (A) The search for } \\
\text { and } \\
\text { understanding }\end{array}$ & $\begin{array}{l}\text { (A1) Discovery of } \\
\text { perspective concept } \\
\text { and competence of } \\
\text { group members }\end{array}$ & $\begin{array}{l}\text { (A2) Pattern discovery } \\
\text { collaborative } \\
\text { interactions solve } \\
\text { problems to reach the } \\
\text { goal }\end{array}$ & $\begin{array}{l}\text { (A3) Understand the } \\
\text { role and function of } \\
\text { problem-solving }\end{array}$ \\
\hline $\begin{array}{l}\text { (B) Providing an } \\
\text { overview of the } \\
\text { workload and setting } \\
\text { the systematic } \\
\text { working pattern }\end{array}$ & $\begin{array}{l}\text { (B1) Building a } \\
\text { common picture } \\
\text { and understanding } \\
\text { the problem go } \\
\text { hand in hand. } \\
\text { (building a } \\
\text { common stand; } \\
\text { common ground) }\end{array}$ & $\begin{array}{l}\text { (B2) Identify and } \\
\text { describe the tasks that } \\
\text { must be accomplished }\end{array}$ & $\begin{array}{l}\text { (B3) Describe the } \\
\text { roles, functions, and } \\
\text { team structure } \\
\text { (methods and etiquette } \\
\text { of communication, } \\
\text { rules, collective } \\
\text { agreements) }\end{array}$ \\
\hline $\begin{array}{l}\text { (C) Planning and } \\
\text { taking action }\end{array}$ & $\begin{array}{lr}\mathrm{C} 1) & \text { Communicate } \\
\text { with } & \text { group } \\
\text { members } & \text { about } \\
\text { what they are doing }\end{array}$ & $\begin{array}{l}\text { (C2) Taking action on } \\
\text { the plan }\end{array}$ & $\begin{array}{l}\text { (C3) Follow the rules } \\
\text { collective agreements } \\
\text { (for example, urging } \\
\text { teammates to be ready }\end{array}$ \\
\hline
\end{tabular}


International Journal of Social Science and Economic Research

ISSN: 2455-8834

Volume:06, Issue:02 "February 2021"

\begin{tabular}{|l|l|l|l|}
\hline & or will be doing & & for an obligation) \\
\hline $\begin{array}{l}\text { (D) Tracking and } \\
\text { reflection }\end{array}$ & $\begin{array}{l}\text { (D1) Follow-up } \\
\text { and amendment to } \\
\text { clarify } \\
\text { understanding to be } \\
\text { mutually agreed } \\
\text { upon }\end{array}$ & $\begin{array}{l}\text { (D2) Performance } \\
\text { evaluation of and the } \\
\text { success of the solution }\end{array}$ & $\begin{array}{l}\text { (D3) Following up, } \\
\text { reflecting, and } \\
\text { reorganizing the team } \\
\text { and the role of group } \\
\text { members }\end{array}$ \\
\hline
\end{tabular}

In conclusion, the above-related studies and synthetics show that collaborative learning can help to develop a teaching model for learners to know ideas, skills, values, thinking methods, and expression methods in learning more easily and more powerfully.In essence, the teaching model to promote the ability to think also focuses on working as a group, where members of the group work together. As well as accepting each other's roles and experiences, they can share knowledge and experiences between members. This research is called collaborative learning. In this research, the researchers were interested in and focused on the above teaching patterns. Also, the researchers have adopted the concept as the basis for the development of a teaching model to promote the ability to think and solve problems in this way.

\section{Research Conceptual Framework}

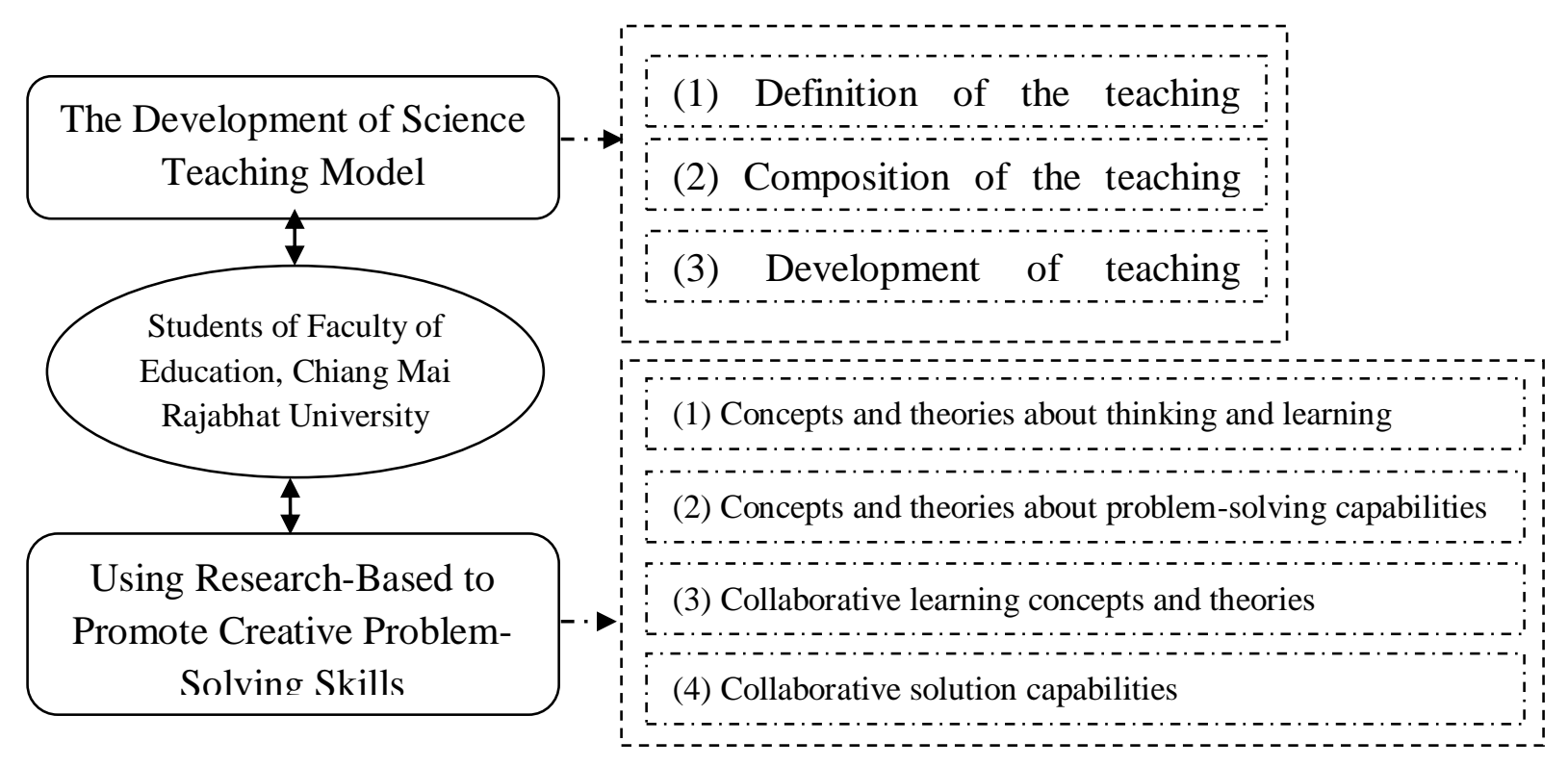

\section{Results}




\section{International Journal of Social Science and Economic Research}

ISSN: $2455-8834$

Volume:06, Issue:02 "February 2021"

1. Results of development and efficiency of the model of teaching science by using research as a base. There are 5 elements which are 1) the principle of focus on the learners that is a systematic creator of knowledge by relying on seeking knowledge through research processes. Learners have an important role in learning through activities that focus on cooperating to learn together with self-guided learning 2) objective to develop creative problem-solving skills 3) management process, the learning process consists of 6 stages: Step 1 is raising awareness of problems that is the step that the teacher can motivate the learners to learn and see the value of what you want to learn and have the direction to be recognized; Step 2 is a problem finding that the instructor encourages the students to propose a problem or ask questions to lead to the third stage of the search. Step 3 is searching how to solve problems that the instructor introduces the research design method and provides the students practice research design for use as guidelines for seeking answers; Step 4 is collecting and data analysis that the instructor trains the learner how to acquire resources, suggest how to collect data and how to build it, guide how to use tool for analyzing data and using various statistics as well as facilitating students to practice perform data collection and analysis to achieve research objectives by the instructor using the process research in teaching, and the students use the research process in learning; Step 5 is summarizing and research finding that instructor trains students to summarize research results to answer assumptions and making recommendations in writing a report, presentation research by the instructor using the research process in teaching, and the students use the research process in Learning and Step 6: Assessing that learners apply research results to society which the students' research results will be assessed by self-assessment, peer-assessment and assessed by teachers. Measurement and evaluation in 2 areas: the field of research skills and creative problem-solving skills. Condition is important to successfully implement patterns that contain the students who have a basic thinking ability, systematic, responsible commitment to work by using research results and research processes as tools in learning and applying problem situations in daily life. The model was found that was applied to the sample with efficiency $\mathrm{E}_{1} / \mathrm{E}_{2}$ to $81.36 / 76.86$

2. Effectiveness of the model was found that; 2.1) students had creative problem-solving skills with significantly higher after studying than before studying at the .05 level, 2.2) students had a development with research skills and creative problem-solving skills. Both as a whole and classified by basic capabilities and learning patterns, and 2.3) students had the durability of highbasic competence research skills and dwarfs and groups with cooperative learning models and students of all groups had the durability of creative problem-solving skills in the follow-up of using the model. 


\section{International Journal of Social Science and Economic Research}

ISSN: 2455-8834

Volume:06, Issue:02 "February 2021"

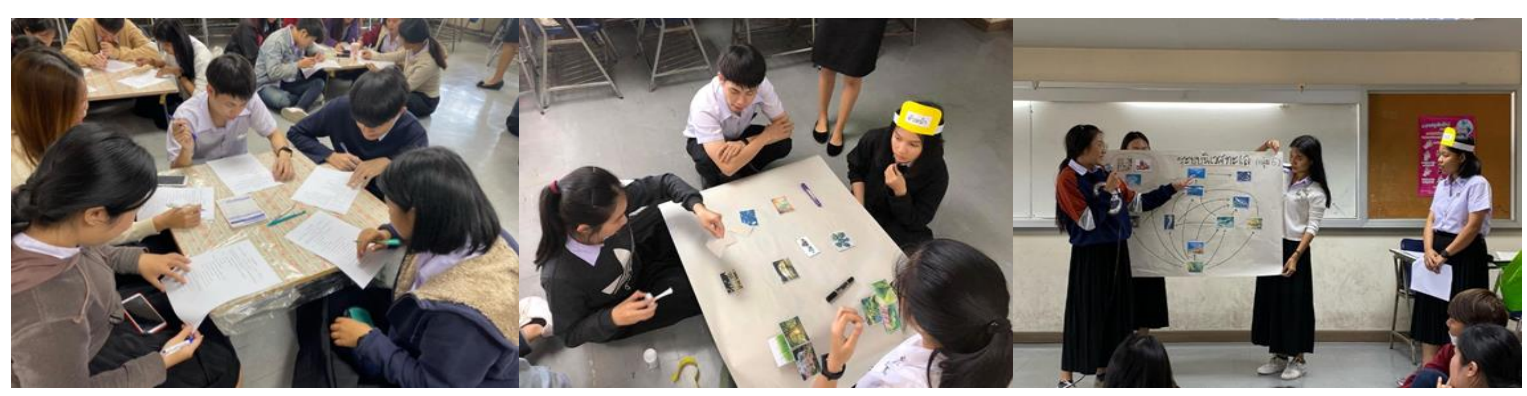

Figure 1:Example of learning activities Cooperative problem-solving process

\section{Discussion}

From the research result of the development of science teaching model by using research-based to promote creative problem-solving skills of students of Faculty of Education, Chiang Mai Rajabhat University, it was found issues that should be discussed as follows:

1. From the results of development and efficiency of science teaching model using researchbased, it was found that the model had a quality of content accuracy and efficiency enough to be used for learning management teaching that was appropriate and covering the want to strengthen research skills, creative problem solving of students. This may be due to be developed, model. There was a procedure in the systematic method by applying the results of fundamental analysis that related to management policy, studies, research results of enGauge (Treffinger, 2007) on developing the skills required of the learners that analyzed the subject matter and standards of the educational curriculum Basic B.E. 2551 (2008) conceptual science Research theory involved in the development of teaching and learning models due to the concept theories that form the basis of teaching and learning which corresponds to the concept of developing a model (Joyce and Weil, 1996: 13; Direction Khaemmanee, 2002) that concluded that the

Teaching is a form of teaching action plan that has been organized systematically about the theory by form teaching and learning form must have theoretical support also had the study of a teacher teaching management conditions and student learning behavior learner analysis about basic abilities basic learning model of research skills and creative problem-solving skills with job analysis and workload to be a guideline in the design of learning management teaching. 


\section{International Journal of Social Science and Economic Research}

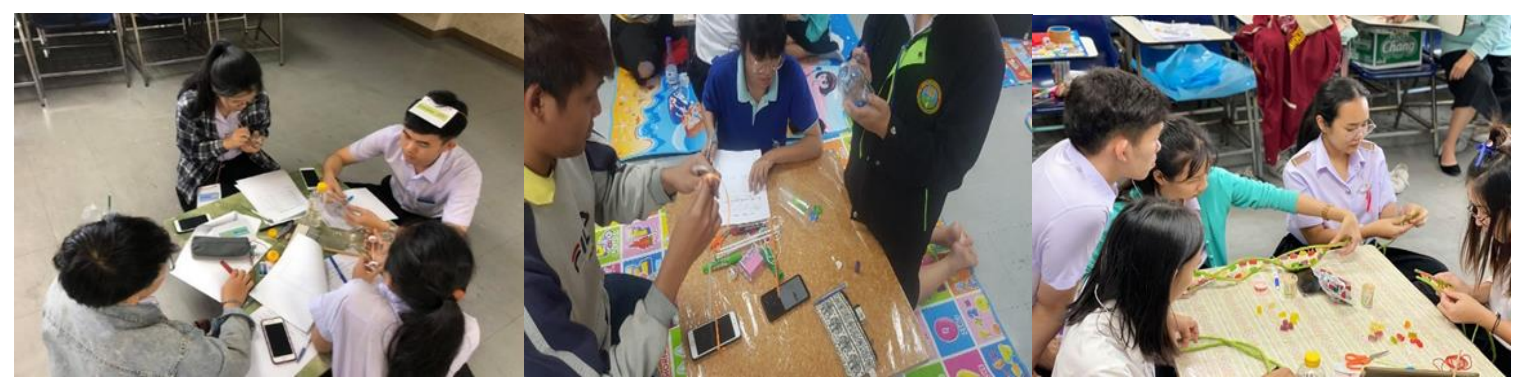

Figure 2:Example of learning activities Cooperative problem-solving process

2. From the evaluation of the effectiveness of a model of teaching science by using researchbased with the following research results:

2.1 Overall, it was found that after studying according to the model of teaching science by using research. It was a student base with strong problem-solving skills. The creativity was significantly higher than before studying at the .05 level and found that the students with basics and learning styles are different, all groups have different skills. Creative problem solving after studying was higher than before studying with statistical significance at the .05 level, which may due to the model developed by the researcher meet the development of creative problem-solving skills of students. The situation has been used in everyday life that meets the needs of studying. It is a constant and varied knowledge of students.

There are activities and teaching materials that encourage students to work together to think, solve problems and consider the causes of real problems with effective solutions. The imagination is creative which is consistent with the research of Pumchat (2009) found that children who were treated style-based experience is capable of creative solve-problems after hosting the experience significantly higher than before hosting the experience with statistics at the .05 level that was consistent with Buppasiri (2009) found that students could solve problems constructively, an average of 82.86 percent of the full score, which was very high, corresponds to Jenjit (2003) found that students with the talent in mathematics studied with teaching activities for geometry using creative solve problems that had cognitive behavior solve problems constructively after studying at a high level. All aspects are also consistent with Ellison (1995). It found that students who had learned to solve problems creatively with higher creativity by having developed creativity in thinking fluency with the highest at the level of significance .05 and consistent with Schiever (1986) found that the Solve Parnes' constructive and tactical problems. Daily teaching of Hilda Taba cognition gave more results when compared to the control group had statistical significance at .01 level from research results that consistent such teachers can develop solve problems creatively for students from kindergarten and should be 


\section{International Journal of Social Science and Economic Research}

ISSN: $2455-8834$

Volume:06, Issue:02 "February 2021"

developed continuously and multiple approaches with an emphasis on responsive processes. The learning needs of students are essential.

2.2 Students with different basic abilities and learning form developed higher research skills during the study until after class from intermediate to a high level. This may be because the student was instructed by teachers and understand the research process more in a manner. There was a data link with creating research questions, research objectives, research hypothesis, formulation source variable, dependent variable, method control variable. Collect information selection of storage tools, data collection as well as data analysis and summarize and discuss the findings. It was also found that the model gave students the persistence of research skills with high and low basic abilities, and students with collaborative and collaborative learning model. This was due to the students who had basic abilities. The high base was well equipped to learn new things and be organized. The systems of thinking were fast including having knowledge in the science of study that was necessary for the use of the process think advanced and summarize knowledge from searching for information to understand and lead to a reasonable discussion of research findings. Teachers had a role in encouraging learners to self-learning in line with the words of Ladda Phu Kiat (2009) that the learning process of research-based science teaching was a study arrangement. Teaching in the subject was mainly and used research as an auxiliary process which teachers still played a role in teaching and organizing the learning process for the learners to achieve in learning while students with low fundamental abilities needed for learning through joint practice activities that were not just listening to lectures from teachers. It was just as important as this student group. They accepted and were part of working in groups, but they were worried that they would not be accepted by friends in the group when the teacher came in to suggest to help and point out the capabilities of members.

Everyone in the group made each student see what matters to themselves and more friends in the group. Students developed higher and have durability in research skills for talented students. Basic, moderate, and participatory learning styles were found that there was a higher improvement in research skills but not yet. The persistence of research skills during the followup phase may be because the student was enough to learn and practice during learning by using a teaching model using research was the base, but after that the teacher did not motivate the students to do activities in the follow-up period, thus enabling student's research skills slightly decreased. It was shown that group students required the use of a continuous model for a while to gain more knowledge and understanding of the process which may give students the persistence of research skills.

2.3 The retention of research skills was found only in the students that had high basic abilities and low basic abilities, the collaborative learning styles, and dependent learning styles, all groups of the students had retention of creative problem-solving skills at the follow-up phase. This may 


\section{International Journal of Social Science and Economic Research}

ISSN: 2455-8834

Volume:06, Issue:02 "February 2021"

be due to the term before learning to the period during the study according to the learning model of research-based science teaching which was the first phase of using the model most students had ready to learn new things together with teachers, technology was a part of the management process to stimulate interest and encourage students to continuous learning through a variety of activities, and still use a process that very complex in the first phase of using the model, but found that the teacher had to help students. It was very new as students learn. Students must be committed very intentional and responsible for study and work. Teachers must play a role in giving advice closely and continuously to stimulate learning. Students had an exchange of knowledge with each other between teacher and student, and students with students. Also found that students had persistence of creative problem-solving skills in the follow-up period using the model. It may be due to when students learned by practicing self-act with understanding in which the use of a model of research-based science teaching will focus on giving students the learning process from implementing every step of the organizing process self-learning styles with teachers waiting and provide advice and follow up continuously, which gave students the knowledge and the ability to make students durable of creative problem-solving skills.

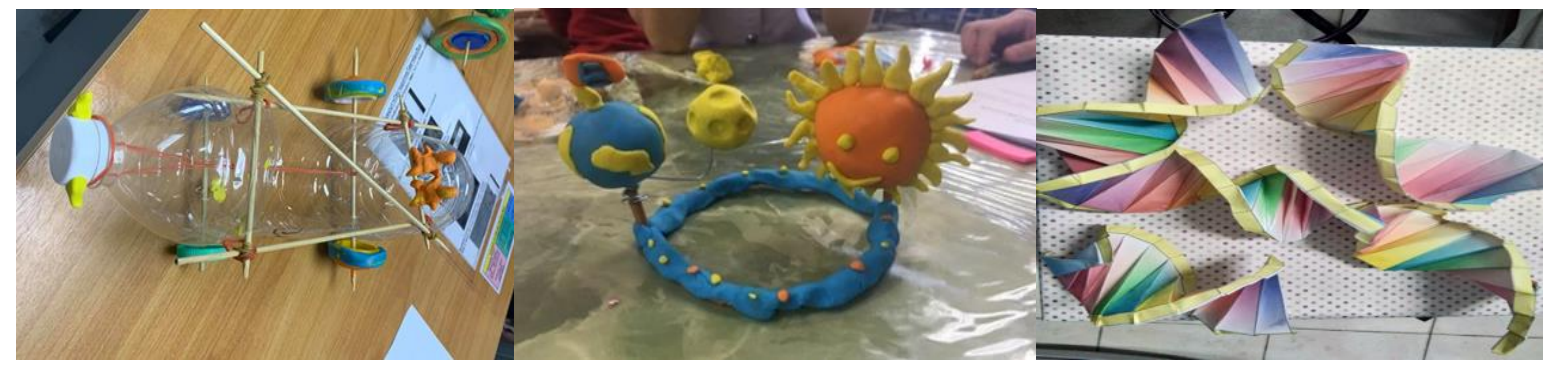

Figure 3: Show the student's workpiece after the learning activity

\section{Conclusion}

The development of the science teaching model by using research-based to promote creative problem-solving skills of students of Faculty of Education, Chiang Mai Rajabhat University can help to improve student performance, before proceeding with learning management through science teaching model by using research-based. Teachers should teach basic knowledge to students because basic knowledge will help students succeed in learning activities. Organizing learning activities with a creative problem-solving model consists of procedures and activities that must be emphasized in practice. Students may take longer to do activities than specified. Therefore, teachers may be flexible as appropriate. For organizing learning activities with a creative problem-solving model, teachers must encourage students to express their opinions and listen to their opinions, and focusing on creating a participatory atmosphere. 


\section{International Journal of Social Science and Economic Research}

ISSN: $2455-8834$

Volume:06, Issue:02 "February 2021"

\section{Acknowledgment}

This research could not have been accomplished smoothly and well without great assistance from the Virapong Saeng-Xuto and Kreetha Kaewkhong, my dissertation advisor and coadvisor, for providing beneficial advice and comments even during his busy times and for his kindness throughout my study. The authors thank the Faculty of Education, Chiang Mai University Thailand for providing instruments.

\section{Reference}

Ablon, J. S., \& Pollastri, A. R. (2018). The school discipline fix: changing behavior using the collaborative problem solving approach. WW Norton \& Company.

Andreu-Andrés, M. Á. (2016). Cooperative or collaborative learning: Is there a difference in university students' perceptions?/Aprendizaje cooperativo o colaborativo: $;$ hay alguna diferencia en la percepción de los estudiantes universitarios?. Revista Complutense de Educación, 27(3), 1041.

Atkins, L. (2013). Researching 'with', not 'on': engaging marginalised learners in the research process. Research in Post-Compulsory Education, 18(1-2), 143-158.

Buppasiri. (2009). Web-Based Instruction Project Based Learning ModelDevelopment for Career Enhance Skill of Industry for SeniorHigh School Student. Journal of Industrial Education, 11(1), 9-21.

Chang, E. C. (2017). Applying the broaden-and-build model of positive emotions to social problem solving: Does feeling good (vs. feeling bad) influence problem orientation, problem- solving skills, or both?. Journal of Social and Clinical Psychology, 36(5), 380-395.

Dieu, H. D. T., Kim, O. D. T., \& Bich, H. N. V. (2018, November). Sustainable Development of Collaborative Problem Solving Competency for Technical Students through Experiential Learning (A Case Study in Planning Skills Subject at Ho Chi Minh city University of Technology and Education). In 2018 4th International Conference on Green Technology and Sustainable Development (GTSD), 505-510. IEEE.

Educational Curriculum Basic. (2008). Educational curriculum Basic B.E. 2551. Chonburi: Chonradsadorn Amrung School.

Ellison. (1995). Creative Problem Solving Through Design Education : An Experimental 


\section{International Journal of Social Science and Economic Research}

ISSN: $2455-8834$

Volume:06, Issue:02 "February 2021"

Study. Canada: Mount Saint Vincent University.

Ennis, R. H. (2018). Critical thinking across the curriculum: A vision. Topoi, 37(1), 165-184.

Gorgônio, F. L., Vale, K. M., Silva, Y. K. N., \& Silva, H. M. (2017). Grouping students for cooperative and collaborative learning: Challenges and trends in virtual learning environments. In IEEE World Engineering Education Conference, Santos, Brazil.Retrieved from http://edunine. eu/edunine2017/proc/works/33. pdf.

Hass, R. W., \& Beaty, R. E. (2018). Use or consequences: Probing the cognitive difference between two measures of divergent thinking. Frontiers in psychology, 9, 2327.

Jeanjenjit, U. (2001). The study of scientific problem-solving abilities and skills Science experiment of 2 nd year chemical engineering students who are taught by computer Help teach experiments Subject to analyzing water samples. Bangkok: Srinakarin University Rintorn Wirot Prasarnmit.

Jenjit. (2003). Teaching and learning activities in geometry using creative problem solving for high school students with a talent in math. Doctor of Education degree thesis Mathematics Program, Graduate School, Srinakharinwirot University.

Joyce and Weil. (1996). Model of Teaching. 5th ed. London: Ally n andBacon.

Karatas, H., Bademcioglu, M., \& Celik, S. (2017). A Study on the Relationship between Problem Solving Skills and Multiple Intelligences of High School Students.

International Journal of Education and Practice, 5(10), 171-181.

Khaemmanee. (2002). "Learning management by learners uses research as part of the learning process: Principles, Guidelines and Methods”. Teaching and learning by students use research as part of the learning process. Bangkok: The Teachers Council of Thailand Press, Ladprao.

Khemmanee. (2005). Pedagogy: Knowledge for effective learning process. 12 th edition. Bangkok: Press Office of Chulalongkorn University.

Ladda Phu Kiat. (2009). Teaching project style and research-based teaching: work that teachers can do. Bangkok: Saha \& Sun Printing Company Limited.

Office of Academic Affairs and Study. (2011). From focus Developing learners ... into the classroom Learning management. 1st edition, Bangkok: Printing house of Agricultural 


\section{International Journal of Social Science and Economic Research}

ISSN: 2455-8834

Volume:06, Issue:02 "February 2021"

Cooperative Federation of Thailand, Ltd.

Laoriendee, W. (2010). Model of learning management strategy for developing thinking skills. 5th edition. Nakhon Pathom: Silpakorn University.

McLeod, S. (2018). Jean Piaget's theory of cognitive development. Simply Psychology.

Mohan, R. (2019). Innovative science teaching. PHI Learning Pvt. Ltd..

Moonkham, S. (2004). Complete the idea of thinking. 3rd edition, Bangkok: Photo prints.

Pollastri, A. R., Ablon, J. S., \& Hone, M. J. (Eds.). (2019). Collaborative Problem Solving:

An Evidence-Based Approach to Implementation and Practice. Springer.

Pumchat. (2009). Developing a model for creating creative problem-solving experiences for Early childhood. Doctor of Philosophy Thesis. Curriculum and Instruction Program,

Graduate school, Silpakorn University.

Scandura, J. M. (2017). Structural Learning (Volume 1): Theory and Research. Routledge.

Schiever. (1986). The Effect of Two Teaching/Learning Model onthe Higher Cognitive Processes of Students in Classes for the Gifted (Parnes CPS, TABA). Dissertation Abstracts International.

Treffinger. (2007). “A New Renaissance? PreparingProductive Thinkers for Tomorrow's World”. Creative Learning Today, 15(4): 1.

Treffinger and Isaksen. (2008). "A New Renaissance? PreparingProductive Thinkers for Tomorrow's World”. Creative Learning Today, 15(4): 1.

Weir. (1974). "Problem solving is everybody'problem.”. The Science Teacher, 41: 16-18.

Zambrano, J., Kirschner, F., Sweller, J., \& Kirschner, P. A. (2019). Effects of prior knowledge on collaborative and individual learning. Learning and Instruction, 63, 101214. 